\title{
The endowment effect on entrepreneurs: A risky attachment*
}

El efecto dotación en emprendedores: Un apego muy riesgoso

\author{
ISABELA ECHEVERRY PEÑóN** \\ Santiago Reyes Ortega***
}

\begin{abstract}
This paper presents evidence on the role of the endowment effect in shaping the risk-taking behavior of entrepreneurs, and how the potential of losing their firms lead them to take higher risks. This study uses an experimental design with 466 entrepreneurs in Cali, Colombia. Results show that entrepreneurs are more likely to accept riskier bets when those are related to the possession of their companies than in non-framed lotteries. The data shows that the existence of the endowment effect increases the certainty equivalent of a lottery, for the median entrepreneur, by $36.5 \%$. This could explain why many entrepreneurs prefer to continue operating their underperforming firms, as well as why many entrepreneurs overvalue their firms during investment processes. This paper presents an alternate view on the drivers behind entrepreneurs' risk-taking behavior and opens a door for future research on the role of biases on entrepreneurs'decision-making processes.
\end{abstract}

Key words: Endowment effect, cognitive biases, entrepreneurship, risk behavior, investment decisions, experimental design.

JEL Classification: L26, G41, D91, C91.

* The authors that contributed to this article did it in their personal capacity. The views expressed are their own and do not necessarily represent the views of their Institutions. This research was possible thanks to the financing of the Cali Chamber of Commerce, as part of its knowledge creation strategy. We would like to thank the valuable comments of Esteban Piedrahita, Alyssa Huberts, Luis Omar Herrera and the attendants to the seminars held at the Cali Chamber of Commerce and the First Conference of the Latin American Network on the Economics of Innovation and Entrepreneurship organized by Inter-American Development Bank. Also, we would like to thank Marcela Torres and Sergio Sierra for their excellent research assistance.

** Cámara de Comercio de Cali. E-mail: iecheverry@ccc.org.co

*** Inter-American Development Bank. E-mail: sreyes@iadb.org

Received: 16 de octubre de 2017. Accepted: 18 de febrero de 2018. 


\section{Resumen}

Este documento presenta evidencia acerca del papel del efecto de dotación en el comportamiento de riesgo de los emprendedores, y cómo el potencial de perder sus empresas los lleva a asumir mayores riesgos. Este estudio utiliza un diseño experimental con 466 emprendedores en Cali, Colombia. Los resultados muestran que los emprendedores son más propensos a aceptar apuestas más arriesgadas cuando estas están relacionadas con la posesión de sus compañías, que en loterías no enmarcadas en este contexto. Los datos muestran que la existencia del efecto de dotación aumenta el equivalente de certeza de una lotería, para el emprendedor medio, en 36,5\%. Esto podría explicar por qué muchos empresarios prefieren continuar operando sus empresas de bajo rendimiento, y también por qué muchos emprendedores sobrevaloran sus empresas durante los procesos de inversión. Este documento presenta una visión alternativa respecto de los factores detrás del comportamiento de riesgo de los emprendedores, y abre la puerta a futuras investigaciones del papel de los sesgos en los procesos de toma de decisiones empresariales.

Palabras clave: Efecto dotación, sesgos cognitivos, emprendimiento, comportamiento de riesgo, decisiones de inversión, diseño experimental.

Clasificación JEL: L26, G41, D91, C91.

\section{INTRODUCTION}

Entrepreneurship is often associated with an individual's ability to make critical decisions in high-risk scenarios. Indeed, the decision of becoming an entrepreneur is a risky one in itself. According to the U.S. Census Bureau, just four out of ten new firms in the US remain in operation after five years, and this number include unprofitable firms. In that sense, people who are less riskaverse are more likely to become entrepreneurs (Caliendo and Kritikos, 2009). However, recent literature has shown that not only risk preferences, but cognitive biases as well, play a major role in the decision-making process of entrepreneurs (Baron, 1998 and Simon et al., 2000). For example, Sandri et al., (2010) finds that entrepreneurs do not behave according to real-options reasoning; rather, their disinvestment decisions have been found to be influenced by behavioral biases, such as the endowment effect, inaction inertia, and decision-avoidance bias, among others. Such behavior might lead entrepreneurs to hold on to their underperforming companies for too long or to decline potential investment offers for their successful firms. Moreover, biases could explain why Holm et al. (2013) find that entrepreneurs are less risk-averse than the general population only in situations that are related to their firms. One of those biases is the endowment effect; a term coined by Thaler (1980) that refers to the tendency of individuals to value their personal possessions more, due merely to the fact that 
they belong to them. This paper examines the role of such endowment effect on entrepreneurs and how the potential of losing their companies might influence their risk-taking behavior.

In the past two decades, literature in the fields of psychology and economics has shown an increasingly advanced understanding of the presence of cognitive biases held by entrepreneurs. Busenitz and Barney (1997) showed that entrepreneurs' decision-making processes are more likely to be based on personal biases and heuristics when compared to managers' decisions. Cooper and Woo (1988) found that entrepreneurs not only perceive their odds of success to be higher than the real ones, but also above those of their peers. Koellinger et al., (2007) identified that entrepreneurs rely on an overconfident view of their situation, leading them to overestimate their likelihood of success. Despite these advances, few studies have analyzed the endowment effect on entrepreneurs and its consequences on risk behavior. The endowment effect predicts that people will value more goods or items that belong to them. Several experiments have tested this hypothesis in multiple settings, and all of them have identified a clear difference between the price a person is willing to pay for an object and the price the same person is willing to accept when selling it (see Kahneman, Knetsch and Thaler, 1991). In the case of entrepreneurs, the difference in valuation relates to their companies. Burmeister and Schade (2007) found that entrepreneurs suffer equally from the status quo bias ${ }^{1}$ as do college students, but less than bankers. In addition, research conducted by Sandri et al. (2010) supported the endowment effect as a possible explanation for entrepreneurs' irrational behavior, contrary to the rational behavior that would be expected under the real-options theory.

However, none has explored the implications of such biases on entrepreneurs' risk behavior. This study advances current literature by exploring risk decisions of real entrepreneurs under different settings. This allow us to take a step in the direction of going from experiments that identify biases to experiments that help understanding how those biases are translated into actions. Furthermore, and to the extent of our knowledge, this is the first behavioral experiment run with entrepreneurs in Latin America, a developing region where uncertainty, and therefore risk, plays a larger role in entrepreneurs' decisions.

This study conducted an experiment with 466 entrepreneurs who participated in ValleE, one of several entrepreneurship support programs run by the Cali Chamber of Commerce in Colombia ${ }^{2}$. The results revealed that entrepreneurs

1 Some studies have used the status quo bias as an indicator of the existence of the endowment effect. Specifically, the status quo bias refers to people placing a higher value on the potential losses from a change in the status quo than its potential gains. This bias can be present due to the aversion of losing current possessions (i.e. the endowment effect). Given the closeness of these two biases, we will report studies that find evidence on the status quo bias as other indication of the possible existence of the endowment effect.

2 The Cali Chamber of Commerce is a private non-profit business development agency. Its main role is that of incorporating new business into the economy. At the same time the Chamber designs and offers enterprise development services thought to help entrepreneurs 
who were faced with a hypothetical risk decision regarding their own companies were more likely to choose the risky option over a safe bet, compared to entrepreneurs faced with the same risk decision in a non-framed lottery, a la Holt and Laury (2002). Moreover, this result is stronger for entrepreneurs with a stronger bond with their actual firms (i.e. those with an established business and whose full-time job is managing the firm). These results are consistent with the existence of the endowment effect on entrepreneurs, and offer an alternative explanation for why entrepreneurs of underperforming firms may choose not to exit the market, as well as for the vast firm valuation spread between entrepreneurs and neutral third-parties.

This paper is divided as follows: Second section presents the theoretical background of the endowment effect and its potential effects on entrepreneurs' risk-taking behavior. The third section describes the experiment and the characteristics of the participating entrepreneurs. The fourth section presents the results of the experiment. Fifth section discusses the implication of the results for the different kind of entrepreneurs. Sixth section shares a series of conclusions and further research questions.

\section{Theoretical BaCkground}

The endowment effect refers to the difference in a person's perceived value of an object or entity before and after they have acquired it. In practice, it is the difference between what a person is willing to pay for an item and the price he will accept for that item once he owns it. Several studies have shown its existence in experiments utilizing multiple objects, such as mugs, pens, and chocolate bars, among others. Most of this research has been led by Daniel Kahneman, Jack Knetsch, and Richard Thaler. As expressed by these authors, the economic consequences of the existence of the endowment effect for the economy are vast: "It [the endowment effect] might produce inertia in the economy because potential traders are more reluctant to trade than is conventionally assumed." (Kahneman et al., 1991). In the context of entrepreneurship and enterprises, that inertia could lead to huge losses for the economy. Consider an inefficient firm and an informed investor who has identified how to improve the firm's efficiency. The investor makes an offer to buy the firm and gain the returns of the efficiency improvement, using a discounted cash flow exercise to value the company. If the owner of the firm includes the compensation value of the utility loss caused by the ownership loss in the asking price, it is very likely that the investment will not occur due to the differences between the investor's willingness to pay and the owner's willingness to accept. Consequently, there will not be productivity gains, nor wage increases, caused by the firm's efficiency improvements.

and companies scale faster, become more productive and efficient which in turn result in economic growth and a better quality of life for the region. 
The same situation might occur with underperforming entrepreneurs. They are faced with the choice of either closing their companies or taking high risks that could result in failure and lost time and resources. Under a constant relative risk aversion (CRRA) utility function and the absence of the endowment effect, the entrepreneur will have to address a choice problem such as that shown in equation 1. Being $\mathrm{X}$ the liquidation value, $p_{1}$ the probability of failure, $\mathrm{Z}$ and $\mathrm{Y}$ the payoffs under success and failure scenarios, respectively, and $\gamma$ the risk aversion parameter.

$$
U=\left\{\begin{array}{c}
X^{1-\gamma} /(1-\gamma) \quad \text { if } \quad \text { firm closes; } \\
\left(1-p_{1}\right)\left(Z^{1-\gamma} /(1-\gamma)\right)+p_{1}\left(Y^{1-\gamma} /(1-\gamma)\right) \quad \text { otherwise } \\
\text { where } X>0 ; Y>X>Z ; \text { and } \gamma \neq 1
\end{array}\right.
$$

Under the special case of $\gamma=1$, the utility of the entrepreneur will be the natural logarithm of $\mathrm{X}$ if the firm closes, and $\left(1-p_{1}\right) \ln (Z)+p_{2}$ otherwise.

Due to the fact that the actual payoffs for the entrepreneurs are unobservable, most of the research that has been done in the literature is based on entrepreneurs' actual choices. In that sense, if there are underperforming firms in the real world, it might be because entrepreneurs are high risk-takers $(\gamma<0)$ or because they are overconfident and overestimate their probability of success $\widehat{p_{1}}$. Some of this literature found evidence of both. Caliendo et al. (2009) found that individuals who are less risk-averse are more likely to become entrepreneurs. Meanwhile, Cooper and Woo (1988), Koellinger et al. (2005), and Simon et al. (2000) identified that entrepreneurs tend to be overconfident, and in some instances, they might not even perceive the magnitude of the risk associated with their ventures.

However, an alternative explanation for the persistence of many underperforming firms is the endowment effect. Under its existence, it would be possible that, for example, a risk-neutral entrepreneur decides to keep his company even if its liquidation value is greater than the expected value of the lottery associated with keeping the business. Also, it would explain why, as Holm et al. (2013) found, entrepreneurs behave differently in situations related to their firms. In a general case, let us define $\varphi$ as the monetary value assigned by the entrepreneur to owning his firm. This parameter will account for the endowment effect and other non-pecuniary benefits of being an entrepreneur relative to being a worker such as time flexibility and autonomy, among others (see Benz, 2009 and Hurst and Pugsley, 2011). As discussed in the next section, this experiment will be able to show the existence of this parameter, but will not be able to separate the role of the endowment effect and the one of the non-pecuniary utility.

In this scenario, the choice problem will be that shown in equation 2 , and the certainty equivalent required for the entrepreneur to sell his company will be that described in equation 3 : 
(2)

$$
U=\left\{\begin{array}{c}
X^{1-\gamma} /(1-\gamma) \quad \text { if close }=1 \\
\frac{\varphi^{1-\gamma}}{(1-\gamma)}+\left[\left(1-p_{1}\right)\left(Z^{1-\gamma} /(1-\gamma)\right)+p_{1}\left(Y^{1-\gamma} /(1-\gamma)\right)\right] \quad \text { if close }=0 \\
\text { where } \varphi \geq 0
\end{array}\right.
$$

Defining $\mathcal{L}(\cdot)=\left(1-p_{1}\right)\left(Z^{1-\gamma}\right)+p_{1}\left(Y^{1-\gamma}\right)$, it follows that:

$$
C E=\left(\varphi^{1-\gamma}+\mathcal{L}(\cdot)\right)^{\frac{1}{1-\gamma}}
$$

The derivative of the certainty equivalent with respect to $\varphi$ will be equal to:

$$
\frac{\partial C E}{\partial \varphi}=\frac{\left(\varphi^{1-\gamma}+\mathcal{L}(\cdot)\right)^{\frac{\gamma}{1-\gamma} * \mathcal{L}(\cdot)}}{\varphi^{\gamma}}
$$

Given that the derivative will always be positive, the larger the endowment effect, the more likely the entrepreneur will prefer the risky bet than the safe choice. As previously mentioned, this will increase the gap between the entrepreneur's and investor's valuations or will cause the underperforming entrepreneur to remain in the market instead of choosing to liquidate his firm.

\section{Experimental Setting}

ValleE is one of the largest entrepreneurship programs in the Pacific region of Colombia. This program is led by the "Red Regional de Emprendimiento del Valle del Cauca" 3 and operated by the Cali Chamber of Commerce. This program is held on a yearly basis and seeks innovative entrepreneurs with a business idea or an established firm, who can potentially create economic growth and long-term employment in the region. Early stage entrepreneurs who are selected into the program receive a series of benefits that target company growth through increasing profits. Program benefits include over one hundred hours of prototyping, business model structure, financial structure, sales, and legal framework workshops (among others). The highest performing entrepreneurs receive eight hours of one-on-one mentoring; free magazine and newspaper ads, scholarships to university programs, and an array of contacts through specialized networking events.

3 Entrepreneurship Network of Valle del Cauca. 
To join the program, entrepreneurs must fill out an online registration form; this form includes questions regarding the type of business, sector, innovation potential, scalability, team composition and overall business growth potential. Because the program has become highly popular regionally, this experiment was able to be conducted on an ample spectrum of entrepreneurs. Participating entrepreneurs completed an additional module that allowed testing for evidence of the endowment effect. To avoid any bias, it was highlighted that the module was part of a research project, and that none of the answers would affect their chances of being selected for the program.

In this extra module, participants were told that the objective of the research was to understand entrepreneurs' behavior, and in order to do that, they would be presented some questions regarding hypothetical scenarios independent from their current projects. Entrepreneurs were randomly placed in one of three treatment arms. The first group was presented a table with the following exercise:

A group of investors has offered to buy your hypothetical project. You must decide whether to sell the project or not. In the chart below you will be presented with 10 different scenarios. For each scenario, you must choose between selling at 800 million pesos (USD 400,000) 4 or not selling. If you choose not to sell, a lottery will be held based on the following rules:

a. With probability $X$ the project will be successful, and you will receive 1,450 million pesos (USD 725,000).

b. With probability (1-X) the project will not succeed, and you will only receive 10 million pesos (USD 5,000).

The chart, as shown in Table 1, presented 10 different scenarios changing the probability of X from $10 \%$ to $100 \%$. The last row was used to identify whether or not the respondents understood the experiment ${ }^{5}$.

The second group received the same exercise, but with a tweak. Instead of mentioning that the decision was regarding their project, it mentioned that it was a manager of a firm asking for the entrepreneur's advice. Specifically, the paragraph read:

A group of investors has offered to buy a firm. The manager's firm asks for your advice you whether to sell the project or not. In the chart below you will be presented with 10 different scenarios. For each scenario you must choose between recommend selling at 800 million pesos (USD 400,000) or not selling. If you recommend not selling, a lottery will be held based on the following rules: (Same rules as above)

\footnotetext{
About USD 320,000 at the time the survey was administered.

$515 \%$ of the entrepreneurs were disqualified either for not answering or answering inconsistently.
} 


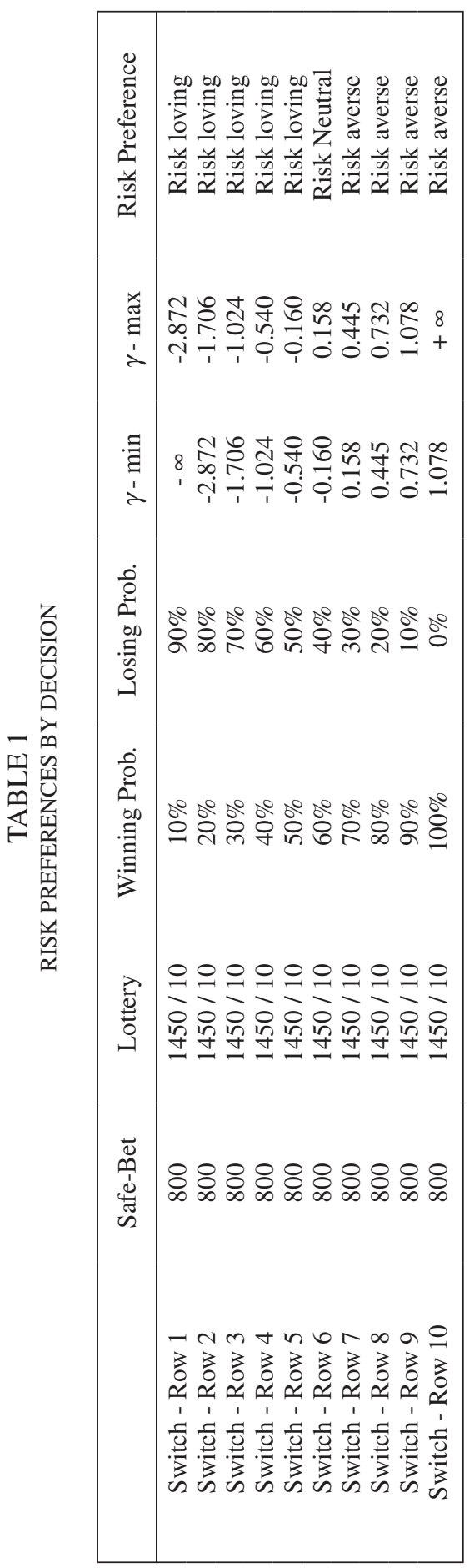


Understanding that entrepreneurs might operate under different risk preferences when deciding for another person and might not reflect their own risk preferences; a third treatment group was included. This third group performed a non-framed experiment, a la Holt and Laury (2002). These entrepreneurs completed the following exercise:

You will be presented with 10 different hypothetical scenarios. Please select in each one, the option you prefer. You can either decide to receive $800 \mathrm{mi}$ llion pesos (USD 400,000), or enter into a lottery where you will have an $X$ probability of winning 1,450 million pesos (USD 725,000) and a (1-X) probability of getting 10 million pesos (USD 5,000). (Similarly, $X$ went from $10 \%$ to $100 \%$ ).

Summarizing, in each of the three exercises, the entrepreneurs are deciding between a safe choice, where they will receive USD 400,000 and a lottery where they can win either USD 725,000 or USD 5,000. By identifying in which row the entrepreneurs decided to switch from the safe bet to the lottery, it is possible to deduce their risk preferences at each specific scenario (see Table 1). Hence, entrepreneurs who switch before row 6 are acting as risk-lovers, risk-neutral entrepreneurs will switch at row 6, and risk-adverse entrepreneurs will switch after row 6. People whose answers were not consistent (i.e. switching multiple times or never switching) were discarded. $15 \%$ of the entrepreneurs had such inconsistent answers.

Given that entrepreneurs were faced with the same hypothetical decisions under different frames; the differences in choices between treatment arms must only be caused by the framing of the question. If entrepreneurs decide to take higher risks just because the question was framed as "your project", it will be an indication of the existence of an endowment effect. Such effect will cause entrepreneurs to have higher certainty equivalents and therefore make them more likely to enter into risky decisions.

As with any other lab experiment, concerns about the external validity and incentives compatibility need to be addressed. First, the decision of not having any real payoffs might influence how entrepreneurs behaved during the experiment. However, given that our objective is to evaluate relative risk behavior across different frames, any bias generated by not having payoffs must be similar between all treatment arms and would not affect our results. Second, the benefit of using real entrepreneurs and having information about their firms, allow us to identify if the differences between treatment arms differ across different types of entrepreneurs (i.e. the ones with an established firm and the ones just with a business idea). As will be shown in the results section, these robustness checks allow us to establish that the evidence of the endowment effect is only present on entrepreneurs with a stronger bond to their firms and therefore, we can rule out any incentives incompatibility of the lab setting (if there is any incentive incompatibility, it should affect all entrepreneurs within each treatment arm). 
Table 2 panel A presents some summary statistics regarding the entrepreneurs and their projects. Most of them are educated males where this entrepreneurship project is their full-time job, although about a half of them are established businesses and the other half are entrepreneurs with a business idea. For 52\% of them, this is not the first business they have created. Their 2014 average annual revenues were $\$ 22,029$, although these range from business ideas with no revenues to a few firms over a million dollars in revenues. Established firms have been in the market on average for almost one year and a half. Panel B shows the differences between the entrepreneurs with valid answers and those that were excluded due to invalid ones. Results show that there are no major differences in terms of the businesses between the valid and the excluded entrepreneurs. However, excluded entrepreneurs were more likely to be less educated, which suggests that they might had some problems understanding the experiment.

TABLE 2

SUMMARY STATISTICS

Panel A: Participants ValleE

\begin{tabular}{|lcccc|}
\hline & Mean & Std Dev & Min & Max \\
\hline Years of operation & 1.80 & 2.62 & 0 & 24 \\
Sales 2013 (USD) & 12,550 & 94,000 & 0 & $2,015,000$ \\
Sales 2014 (USD) & 20,600 & 105,000 & 0 & $1,690,000$ \\
Total Employees & 3.52 & 6.92 & 0 & 76 \\
\% Established Firms & $48.08 \%$ & $50.01 \%$ & 0 & 1 \\
\% Male & $66.16 \%$ & $48.55 \%$ & 0 & 1 \\
\% High-school or less & $9.35 \%$ & $29.13 \%$ & 0 & 1 \\
\% Bachelor's or Tech degree & $73.08 \%$ & $44.39 \%$ & 0 & 1 \\
\% Master's or Phd & $17.57 \%$ & $34.56 \%$ & 0 & 1 \\
\% Serial Entrepreneur & $51.19 \%$ & $50.03 \%$ & 0 & 1 \\
Full-time dedication $(\%)$ & $65.27 \%$ & $47.66 \%$ & 0 & 1 \\
\hline
\end{tabular}

$\mathrm{N}=547$.

Panel B: Differences Valid vs Invalid Answers

\begin{tabular}{|lccc|}
\hline & $\begin{array}{c}\text { Mean Valid } \\
(1)\end{array}$ & $\begin{array}{c}\text { Mean Invalid } \\
(2)\end{array}$ & $\begin{array}{c}\text { t-test } \\
(1) \text { vs }(2)\end{array}$ \\
\hline Years of operation & 1.79 & 1.86 & 0.865 \\
Sales 2013 (USD) & 13,350 & 7,950 & 0.632 \\
Sales 2014 (USD) & 22,050 & 12,450 & 0.449 \\
Total Employees & 3.37 & 4.36 & 0.237 \\
\% Established Firms & $48.93 \%$ & $43.21 \%$ & 0.342 \\
\% Male & $68.06 \%$ & $55.55 \%$ & 0.028 \\
\% High-school or less & $8.37 \%$ & $14.81 \%$ & 0.066 \\
\% Bachelor's or Tech degree & $74.23 \%$ & $66.67 \%$ & 0.157 \\
\% Master's or Phd & $17.40 \%$ & $18.52 \%$ & 0.808 \\
\% Serial Entrepreneur & $52.79 \%$ & $41.98 \%$ & 0.072 \\
Full-time dedication $(\%)$ & $65.45 \%$ & $64.20 \%$ & 0.827 \\
\hline
\end{tabular}

(1) $\mathrm{N}=466$ (2) $\mathrm{N}=81$. 
Table 3 presents the summary statistics and p-values of the differences between treatment arms. This table shows no major differences between treatment arms, except some minor differences in education. Specifically, entrepreneurs who answered the experiment regarding their hypothetical companies are slightly less educated than entrepreneurs in the other two treatment arms. Next section will show this difference is very small and does not affect any of the main conclusions of the paper.

\section{Results}

All entrepreneurs who participated in the experiment were presented with the same kind of deal: Receiving $\$ 400,000$ or entering a risky bet, a lottery that would result in winning $\$ 725,000$ or receiving $\$ 5,000$. Also, as shown in section 3 , the entrepreneurs of all treatment arms are similar both in terms of their personal characteristics and their business projects. In this context, the differences in the subject's decisions should be caused by the framing of the questions in this experiment.

Table 4 presents the risk attitudes of entrepreneurs by question's frame, according to which row they switched at. The results show that entrepreneurs who were faced with the decision regarding their firm were willing to go into higher risks than the entrepreneurs facing the other scenarios. While $19 \%$ and $12 \%$ of the entrepreneurs had switched by row 3 when the decision was regarding

TABLE 3

SUMMARY STATISTICS BY TREATMENT ARM

\begin{tabular}{|c|c|c|c|c|c|c|}
\hline & (1) & (2) & (3) & \multicolumn{3}{|c|}{$\mathrm{p}$-values } \\
\hline & $\begin{array}{c}\text { Sell } \\
\text { treatment } \\
\text { (a) }\end{array}$ & $\begin{array}{l}\text { Advice } \\
\text { treatment } \\
\text { (b) }\end{array}$ & $\begin{array}{l}\text { Control } \\
\text { (c) }\end{array}$ & (1 vs 2$)$ & (1 vs 3$)$ & (2 vs 3$)$ \\
\hline Years of operation & 1.83 & 2.41 & 1.62 & 0.30 & 0.47 & 0.07 \\
\hline Sales 2013 (USD) & 9,650 & 8,550 & 18,900 & 0.85 & 0.40 & 0.54 \\
\hline Sales 2014 (USD) & 21,450 & 16,750 & 24,650 & 0.72 & 0.80 & 0.61 \\
\hline Total Employees & 4.69 & 3.67 & 3.38 & 0.29 & 0.15 & 0.21 \\
\hline$\%$ Established Firms & $47.9 \%$ & $44.7 \%$ & $51.5 \%$ & 0.64 & 0.48 & 0.31 \\
\hline$\%$ Male & $58.3 \%$ & $65.8 \%$ & $66.7 \%$ & 0.32 & 0.23 & 0.90 \\
\hline$\%$ High-school or less & $11.3 \%$ & $3.9 \%$ & $7.1 \%$ & 0.06 & 0.15 & 0.34 \\
\hline $\begin{array}{l}\text { \% Bachelor's or Tech } \\
\text { degree }\end{array}$ & $75.3 \%$ & $76.3 \%$ & $72.3 \%$ & 0.86 & 0.51 & 0.50 \\
\hline$\%$ Master's or Phd & $13.4 \%$ & $19.7 \%$ & $20.7 \%$ & 0.19 & 0.06 & 0.87 \\
\hline$\%$ Serial Entrepreneur & $55.7 \%$ & $43.4 \%$ & $53.6 \%$ & 0.07 & 0.68 & 0.13 \\
\hline Full-time dedication (\%) & $67.0 \%$ & $71.1 \%$ & $61.7 \%$ & 0.52 & 0.28 & 0.15 \\
\hline
\end{tabular}

(a) $\mathrm{N}=194$ (b) $\mathrm{N}=76$ (c ) $\mathrm{N}=196$. 
TABLE 4

RISK PREFERENCES BY FRAME

\begin{tabular}{|lcccc|}
\hline & $\begin{array}{c}\text { Very Risky } \\
\text { (row 1-3) }\end{array}$ & $\begin{array}{c}\text { Risky } \\
\text { (row 4-5) }\end{array}$ & $\begin{array}{c}\text { Neutral Risk } \\
\text { (row 6) }\end{array}$ & $\begin{array}{c}\text { Risk Adverse } \\
\text { (row 7-10) }\end{array}$ \\
\hline Sell treatment & $34 \%$ & $33 \%$ & $15 \%$ & $18 \%$ \\
Advice treatment & $\mathbf{1 9 \%}$ & $\mathbf{4 2 \%}$ & $16 \%$ & $23 \%$ \\
Control & $\mathbf{1 2 \%}$ & $30 \%$ & $18 \%$ & $\mathbf{4 0 \%}$ \\
\hline
\end{tabular}

Note: Bold percentages identify that the proportions are statistical different at a $95 \%$ confidence level, relative to the experiment framed as "your hypothetical firm".

a third-party firm or a non-framed lottery, this percentage increases to $34 \%$ when entrepreneurs had to choose to either sell their company or take the lottery. Interestingly, the median entrepreneur behaved as a risk/taker under the two scenarios that involved making a strategic decision about a firm, whereas the median entrepreneur in the non-framed lottery was neutral to risk. This evidence coincides with the results of Holm et al. (2013), where they find that entrepreneurs are more willing to accept higher levels of uncertainty when the decision is related to competition and strategy than in non-strategic scenarios.

Table 5 presents the results of an ordered logit model using the switch row as a dependent variable. The evidence confirms the descriptive evidence mentioned above. The log-odds of entrepreneurs faced with the decision regarding their firm switching earlier are significantly higher than the ones of entrepreneurs faced with any of the other two question's frames. The results are stable when adding control variables of the entrepreneur or their business model. In terms of odds ratio, entrepreneurs who were faced with "your firm" frame were $35 \%$ and $68 \%$ more likely to switch earlier than those faced with decisions regarding a third-party firm or a non-framed lottery. Again, from the median entrepreneur perspective, this is observed by a change in $\gamma$ from -0.001 to -0.35 , turning a neutral risk entrepreneur into a risk-taker.

In order to address concerns regarding incentives compatibility, Table 6 presents the results of the question framing over different types of entrepreneurs. Although those interactions do not come from the experimental setting, they help shedding light on explaining if the results do come from the endowment effect. Column 1 shows that the entrepreneurs more affected with the framing of the question, and therefore with an endowment affect, are the entrepreneurs that already had an established firm and those that devote their full-time to their firms. That is, entrepreneurs with stronger ties with their firms and consequently, those who would face a higher emotional cost of leaving their firms. Moreover, columns 2 and 3 shows that there is only evidence of an endowment effect on entrepreneurs with an established firm and not on those with a business idea. This result refutes any incentive incompatibility hypothesis such as that entrepreneurs faced with the question regarding their firm would change their behavior 


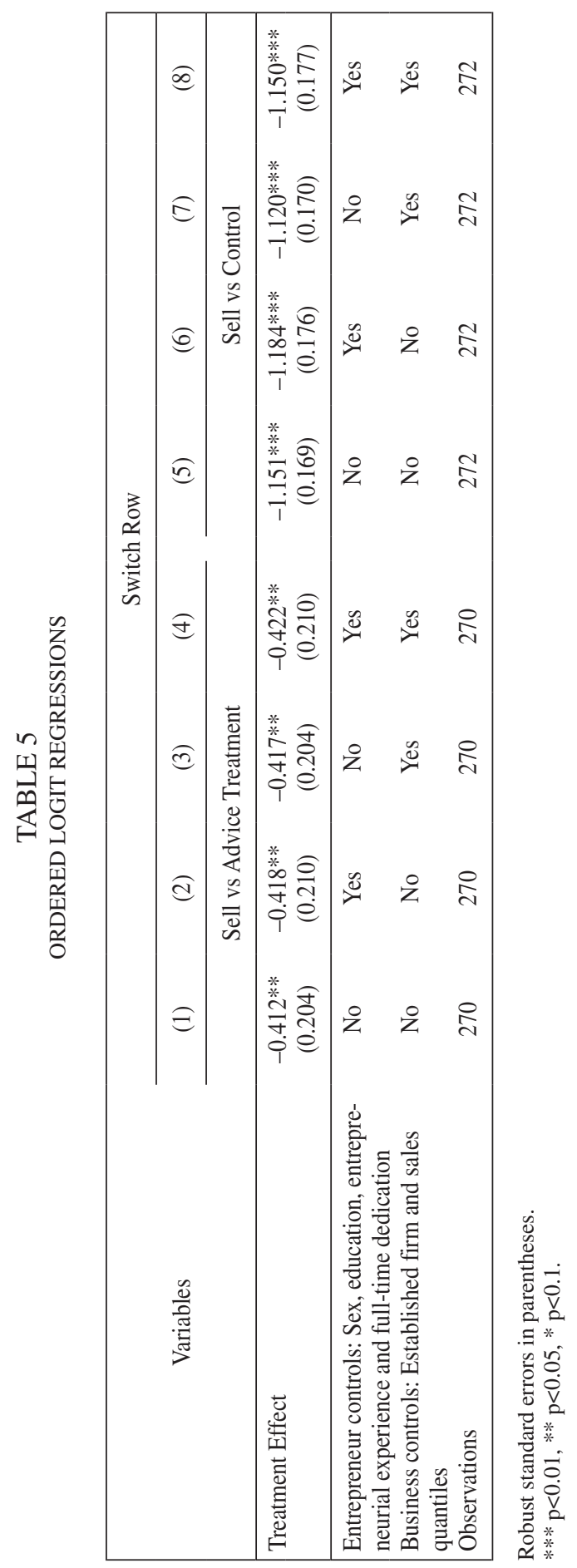


TABLE 6

ROBUSTNESS CHECK

\begin{tabular}{|c|c|c|c|}
\hline \multirow[b]{3}{*}{ Variables } & \multicolumn{3}{|c|}{ Switch Row } \\
\hline & (1) & (2) & (3) \\
\hline & Pooled & $\begin{array}{c}\text { Business } \\
\text { Owners \& } \\
\text { Full-time } \\
\text { dedication }\end{array}$ & $\begin{array}{c}\text { Business } \\
\text { Ideas \& } \\
\text { Part-time } \\
\text { dedication }\end{array}$ \\
\hline Treatment Effect (“Your Firm”) & $\begin{array}{c}1.056 \\
(0.639)\end{array}$ & $\begin{array}{c}-0.673 * \\
(0.373)\end{array}$ & $\begin{array}{c}0.752 \\
(0.591)\end{array}$ \\
\hline Dedication Full-time & $\begin{array}{c}0.429 \\
(0.287)\end{array}$ & & \\
\hline Treatment $*$ Full-Time & $\begin{array}{c}-0.804 * \\
(0.435)\end{array}$ & & \\
\hline Established Firm & $\begin{array}{l}0.648 * * \\
(0.324)\end{array}$ & & \\
\hline Treatment $*$ Established Firm & $\begin{array}{c}-0.904 * * \\
(0.439)\end{array}$ & & \\
\hline $\begin{array}{l}\text { Entrepreneur controls: Sex, educa- } \\
\text { tion, entrepreneurial experience }\end{array}$ & Yes & Yes & Yes \\
\hline Business controls: Sales quantiles & Yes & Yes & Yes \\
\hline Treatment arms & Yes & Yes & Yes \\
\hline Observations & 466 & 209 & 55 \\
\hline
\end{tabular}

Robust standard errors in parentheses.

$* * * \mathrm{p}<0.01, * * \mathrm{p}<0.05, * \mathrm{p}<0.1$.

just to pretend to be risk-takers in front of the organizers of the contest. If that hypothesis was true, the effect would be reflected both on the entrepreneurs with ideas and on those with an established firm. Overall, these results indicate that the higher the ties the entrepreneur has with the firm, the more likely he is to enter into risky bets in order to avoid "selling" his firms. This is completely consistent with the endowment effect bias and is evidence that this is probably the main mechanism behind our results.

The other robustness check that is required is terms of the sample size and possible outliers. Given that our effective sample size is 466 observations, it is possible that outliers could affect our average treatment effect. To show the robustness of our results, we implemented the randomization inference methodology as described by Athey and Imbens (2017). Graph 1 shows how our estimates fare against randomized permutations of treatments for our pooled sample. In only $0.8 \%$ of the randomized treatment samples, the results shown a larger effect -in absolute terms- than our estimated one. This confirms the robustness of our results and excludes the hypothesis that outliers might be driving our results.

The economic impact of the existence of the endowment effect in monetary terms is very high. For example, let us take the median entrepreneur under 


\section{GRAPH 1}

\section{RANDOMIZATION INFERENCE}

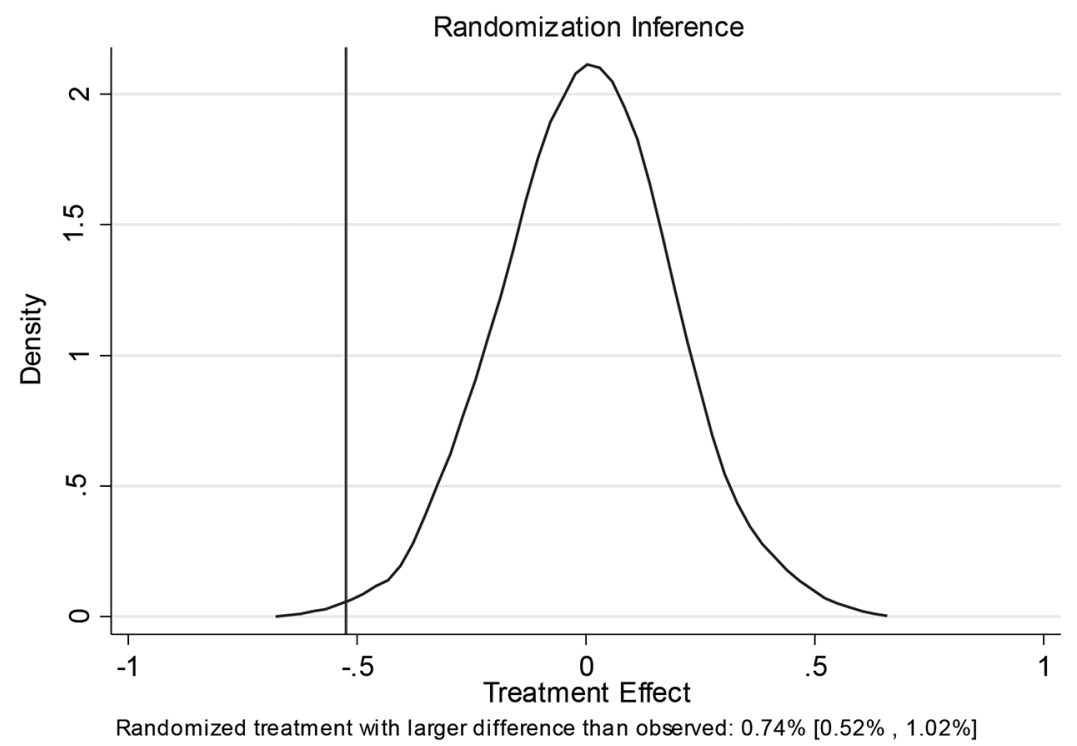

the non-framed lottery, who behaves as a risk neutral individual. If he runs a company that has a forty percent probability of success, he would generally require \$586 million pesos to sell it. However, the median entrepreneur under the existence of an endowment effect would now require $\$ 800$ million pesos, increasing the certainty equivalent by $36.5 \%$. The consequences that such increase might have on an investment process or on any business decision that might affect the ownership of the firm are quite large. Firms will be less dynamic under the endowment effect, taking the economy well below its production frontier.

\section{Discussion}

The existence of the endowment effect on entrepreneurs presents new challenges for policy-makers. From one perspective, underperforming entrepreneurs will stick to their firms, not allowing its resources to flow to more productive firms. By contrast, high potential entrepreneurs will increase the value of their firms and reduce the likelihood of receiving external investments. This will produce smaller firms that rely only on internal financing or banking services. This section will discuss the implications of the endowment effect for underperforming firms and high potential entrepreneurs, and how these results fit within the current literature. 


\subsection{Implications for underperforming firms}

As mentioned above, the main implication of the existence of the endowment effect in underperforming entrepreneurs is an additional cost for entrepreneurs to close their firms. This effect will go in the same direction as other biases found in the entrepreneurship literature, reinforcing their decision to keep their firms open. For example, Koellinger et al. (2007) identifies that entrepreneurs tend to overestimate their likelihood of success. That overconfident view of their situation will cause that even if their firms are underperforming, they expect them to improve in the future. Moreover, Sandri et al. (2010) identifies that cognitive biases such as inaction inertia and the decision-avoidance bias tend to go in the same direction by making disinvestment decisions harder for entrepreneurs.

In addition to those biases, the decision of closing a firm is more complex in reality. Entrepreneurs do not only face a lottery between keeping the firm alive or closing it. If they choose to close it, then they must face the search costs of finding a job. In some cases, the costs of searching for a job and maybe staying unemployed for a period of time might be higher than keeping their underperforming firm. In that sense, some other biases such as loss aversion might play a role in their decisions. If so, the entrepreneurs behind underperforming firms might be trapped in a situation where overconfidence, decision-avoidance bias, loss aversion and the endowment effect will reinforce each other and lead entrepreneurs to stay with their firms.

In terms of policy, these results imply that governments should be aware of the negative consequences of encouraging people to start their firms if they do not have a clear business model. Once entrepreneurs open their firms, all their biases will push them to remain with them even if they are underperforming. A recent paper by Martinez et al. (2018) goes in that direction and evaluates the impact of training and assets for micro-entrepreneurs. They find that giving micro-entrepreneurs training increases their income, not due to a better performance of their businesses, but due to better outcomes in the labor market. In contrast, they find that giving them assets makes them more likely to stay with their firms.

\subsection{Implications for high potential firms}

So far, most of the literature regarding investment processes constraints focus on the principal-agent problem. Amit, Glosten and Muller (1990) model the entrepreneurs' decisions to receive an investment depending on their preferences and their set of skills. Kaplan and Stromberg (2001) show how venture capital firms solve the agency problem by screening, monitoring and contracting. However, investment theory does not take into account how biases affect the decisions entrepreneurs make. For example, the experiment shows that entrepreneurs would increase their certainty equivalent if they must give up their entire firm. A case could be made that those results still apply even if they do not give up $100 \%$ of their firm given that either way entrepreneurs would be losing some 
possession (shares). Further research needs to be done to fully understand how and when and endowment effect could kick in.

If the case is that the endowment effect still applies for shares of their firm, the consequences on investment process would be vast. As estimated above, on average, the endowment effect could increase the certainty equivalent by $36.5 \%$. This will imply that investors must identify large enough business opportunities that the entrepreneur had not -and therefore had not incorporated in its original valuation - to compensate for the endowment effect and decide to invest in the company.

In practice, it seems that investors have found ways to avoid dealing with such biases, at least in the short term. As found by Kaplan and Stromberg (2003), the most preferred investments vehicles come from venture debt and convertible notes, to innovative vehicles like SAFE and KISS instruments, created by Y-Combinator and 500 Startups, respectively. Our interpretation on the preference of such instruments is that they postpone the valuation decision to a point where more information is available and therefore any deviation from the market price could be attributed to entrepreneurs' preferences. This noticeable difference then can be negotiated and market information could be used to “de-bias" entrepreneurs' valuation.

Further research needs to be done in order to incorporate biases into investment theory and how the existence of the endowment effects will affect the contracts preferred by entrepreneurs and investors. Moreover, it is important to evaluate how different investment vehicles might foster the development of financial markets in developing countries where many of them have not been implemented.

\section{Conclusions}

This experiment provides evidence on the existence of the endowment effect and moreover, about its consequences in terms of risk behavior among entrepreneurs and firm owners. Just facing the simple thought of making a hypothetical decision on their project, made entrepreneurs to behave more as risk-loving individuals than how they usually behave in non-framed lotteries. These results must be taken in the context of a laboratory experiment and external validity still needs to be tested. On that note, it is important to highlight that this experiment: i) uses real entrepreneurs, ii) does not create any moral dilemmas that might affect their behavior in the lab (see Levitt and List, 2007), and iii) any bias generated by the experiment must be similar between all treatment arms so the results would not change. These reasons provide an encouraging argument to expect similar behavior under similar situations in the real world.

So far, the literature has focused on identifying what biases entrepreneurs might suffer. This paper goes a step forward in showing how one of those biases, the endowment effect, alters the risk decisions entrepreneurs make. Usually, people think about entrepreneurs as risk-loving people that live their life on the 
edge, making risky and bold moves in order to grow their companies. However, what this experiment shows is that although on average entrepreneurs do not behave as risk-averse people, some of the risk decisions that entrepreneurs make are driven by the fear of losing their firms. Moreover, the higher the ties the entrepreneur has to the firm, the existence of an endowment effect seems more likely.

The implications of such behavior differ between underperforming firms and high potential entrepreneurs. For underperforming entrepreneurs, all possible biases lead them to keep their firms open longer than optimal. Further research needs to be done in order to understand how to overcome those biases. Experiments that try to nudge entrepreneurs' behavior or training programs that get entrepreneurs closer to the labor market are candidates for further analysis.

In terms of high potential entrepreneurs, this experiment shows that the endowment effect could increase the certainty equivalent of a lottery by $36.5 \%$. Such an increase will reduce the likelihood of receiving investments and could limit their growth potential. Flexible and innovative contracts might be a good way of solving the existence of the endowment effect. Kaplan and Stromberg (2003) find evidence that contracts that postpone valuations such as convertible notes are the most frequently used by VCs in the US. More research needs to be done in order to understand the role of behavioral biases in principal-agent problems in investment theory, and furthermore, what type of contracts could foster entrepreneurial investment in developing countries.

\section{RefERENCES}

Amit, R., Glosten, L. and Muller, E. (1990). "Entrepreneurial ability, venture investments, and risk sharing". Management Science, Vol. $36 \mathrm{~N}^{\circ} 10$, pp. 1233-1246.

Athey, S., \& Imbens, G. W. (2017). “The econometrics of randomized experiments". Handbook of Economic Field Experiments, Vol. 1, pp. 73-140.

Baron, R. A. (1998). "Cognitive mechanisms in entrepreneurship: Why and when entrepreneurs think differently than other people". Journal of Business Venturing, Vol. $13 \mathrm{~N}^{\mathrm{o}}$ 4, pp. 275-294.

Benz, M. (2009). Entrepreneurship as a non-profit-seeking activity. International Entrepreneurship and Management Journal, Vol. $5 \mathrm{~N}^{\mathrm{o}}$ 1, pp. 23-44.

Burmeister, K. and Schade, C. (2007). “Are entrepreneurs' decisions more biased? An experimental investigation of the susceptibility to status quo bias". Journal of Business Venturing, Vol. 22 No 3, pp. 340-362.

Busenitz, L. W. and Barney, J. B. (1997). "Differences between entrepreneurs and managers in large organizations: Biases and heuristics in strategic decision-making". Journal of Business Venturing, Vol. 12 No 1, pp. 9-30.

Caliendo, M., Fossen, F. M. and Kritikos, A. S. (2009). "Risk attitudes of nascent entrepreneurs-new evidence from an experimentally validated survey". Small Business Economics, Vol. 32 № 2, pp. 153-167. 
Cooper, A. C., Woo, C. Y. and Dunkelberg, W. C. (1988). "Entrepreneurs' perceived chances for success". Journal of Business Venturing, Vol. 3 $\mathrm{N}^{\circ} 2$, pp. 97-108.

Holm, H. J., Opper, S., \& Nee, V. (2013). "Entrepreneurs under uncertainty: An economic experiment in China". Management Science, Vol. $59 \mathrm{~N}^{\mathrm{o}} 7$, pp. 1671-1687.

Holt, C. A. and Laury, S. K. (2002). "Risk aversion and incentive effects". American Economic Review, Vol. 92 N $^{\circ}$ 5, pp. 1644-1655.

Hurst, E., \& Pugsley, B. W. (2011). "What do small businesses do?". National Bureau of Economic Research. No. w17041.

Kahneman, D., Knetsch, J. L. and Thaler, R. H. (1991). "Anomalies: The endowment effect, loss aversion, and status quo bias". The Journal of Economic Perspectives, Vol. $5 \mathrm{~N}^{\circ}$ 1, pp. 193-206.

Kaplan, S. N. and Stromberg, P. (2001). "Venture capitalists as principals: Contracting, screening, and monitoring". National Bureau of Economic Research, No. w8202.

Kaplan, S. N. and Strömberg, P. (2003). "Financial contracting theory meets the real world: An empirical analysis of venture capital contracts". The Review of Economic Studies, Vol. 70 N$^{\circ} 2$, pp. 281-315.

Koellinger, P., Minniti, M. and Schade, C. (2007). "'I think I can, I think I can': Overconfidence and entrepreneurial behavior". Journal of Economic Psychology, Vol. $28 \mathrm{~N}^{\circ}$ 4, pp. 502-527.

Levitt, S. D. and List, J. A. (2007). "Viewpoint: On the generalizability of lab behaviour to the field". Canadian Journal of Economics/Revue Canadienne D'économique, Vol. $40 \mathrm{~N}^{\circ}$ 2, pp. 347-370.

Martínez, C., Puentes Encina, E. and Ruiz Tagle, J. (2018). "Do MicroEntrepreneurship Programs Increase Wage-Work? Evidence from Chile". American Economic Journal: Applied Economics, forthcoming.

Sandri, S., Schade, C., Musshoff, O. and Odening, M. (2010). "Holding on for too long? An experimental study on inertia in entrepreneurs' and nonentrepreneurs' disinvestment choices". Journal of Economic Behavior \& Organization, Vol. $76 \mathrm{~N}^{\circ}$ 1, pp. 30-44.

Simon, M., Houghton, S. M. and Aquino, K. (2000). "Cognitive biases, risk perception, and venture formation: How individuals decide to start companies". Journal of Business Venturing, Vol. $15 \mathrm{~N}^{\mathrm{o}}$ 2, pp. 113-134.

Thaler, R. (1980). "Toward a positive theory of consumer choice". Journal of Economic Behavior \& Organization, Vol. 1 No 1, pp. 39-60. 
